\title{
Itt lehet vagy kell maradni?
}

\author{
Mobilitástörténetek
}

\author{
NAGY TERÉZIA ${ }^{1}$
}

\begin{abstract}
ABSZTRAKT
A mobilitástörténeteket fókuszba állító esettanulmányban a mobilitás ellenében ható tapasztalatokat vettem sorra. Azaz arra vagyunk kíváncsiak, hogy az egyéni tapasztalatok (tanulmányok, munkavállalás), akár kisebb, akár nagyobb városban vagy külföldön, illetve a kisebb mobilitások (nyaralás, ügyintézés a városban), hogyan hatnak a város-falu kettôsére és a falu iránti elköteleződésre. E vizsgálódást egészíti ki a szülők tapasztalatainak bevonása: az ő mobilitásuk és ez alapján a mobilitás iránti pro és kontra elkötelezettsége nem elhanyagolható hatást jelent a mobilitásra és a maradásra. Az esettanulmány a párban elkészült interjúkon alapul: az immobil fiatal és szülei beszélnek a maradás okairól, a vágyaikról, az elkötelezôdéseikrôl, a tapasztalataikról és arról, hogy a fiatal felnőtteknek van-e esélye maradni vagy menni. Az immobilitás megértésében a családi háttérben jelen lévő migrációs tapasztalat, a közösség és a hozzátartozók migrációs kultúrája, a tapasztalatok, az átadható félelmek és remények megismerése segített a szülői oldalról. A fiatalok oldaláról a sikerek, kudarcok, félelmek, egyéni és családi tapasztalatok irányából látjuk az „immobilitási potenciált”.
\end{abstract}

KULCSSZAVAK: immobilitás, döntések, önkéntes immobilitás, területi folytonosság, kizárás, migráció hiánya, hátrányos helyzet

\section{ABSTRACT}

\section{Here you can or should stay? Narratives of mobility}

In this case study that focuses on mobilities' narratives, we exam the experiences that works against mobility. Thus we are curious how to effect individual experiences (studies, employees), possibly in a larger city or abroad, small mobilities (vacation, office work in a city), how to effect on the duality of city and village as well as on commitment to their village. Involving the experiences of parents complement it and role a significant effect on the youth's mobility and settlement. The case study is based on some pair of interviews: immobilized youth and parents talk about the causes of settlement, desires, commitment, experiences, and about young adults have chance to stay or to migrate. Understanding immobility is about exam the recent and past

\footnotetext{
${ }^{1}$ Egyetemi adjunktus, Debreceni Egyetem Szociológia és Szociálpolitika Tanszék, nagy.terezia@arts. unideb.hu
} 


\section{TEMATIKUS TANULMÁNYOK - Községekben élő immobil fiatalok}

family experiences present in the family at the parent's side, the migration culture of the local community and relatives, the separation of experiences, transmissible fears and hopes. These have to be completed by the young adults' interview where we found the „immobility potential” towards successful, failures, fears, individual and family experiences.

KEYWORDS: immobility, decisions, involuntary immobility, spatial continuity, exclusions, absence of migration, disadvantage

\section{Bevezetés}

Az „Itt lehet vagy kell maradni? Mobilitástörténetek” esettanulmány célja, hogy megismerjük azokat a mintákat és tapasztalatokat, amelyekkel a két különböző generációba tartozó interjúalanyaink rendelkeznek. Célom az, hogy láthatóvá váljon az elemzés során, hogy a kistelepülésen élők milyen mobilitásokat ismernek, milyen tapasztalatokat szereztek közvetlenül és milyen tudással rendelkeznek róla, legfőképpen pedig az, hogy lássuk, e vonatkozásban mi az, ami immobillá teszi a fiatalokat. Az esettanulmány elkészítése során mind a szülői interjúkat, mind a fiatalok interjúit vizsgáltam, a mobilitás-tapasztalatokra koncentráltam. Az interjúk az MTA Kiválósági Együttműködési Programja, Mobilitás Kutatási Centrum programja keretében a Debreceni Egyetemen zajlott kutatás keretében készültek el, melynek során olyan 19-25 éves fiatalokat és szüleiket kerestünk meg, akik a falujukban (kistelepüléseiken) maradtak, még akkor is, ha korábban - akárcsak tanulmányaik miatt - mobilitást mutattak. Ezen esettanulmány a tapasztalatokra és azok értékelésére koncentrál: milyen volt máshol élni, s mi vezetett oda, hogy az interjúalany immobillá vált.

Az esettanulmány fő dimenziói tehát a mobilitástörténetet bontják ki: hogyan látják a mobilitást a szülők és fiatalok generációi, voltak-e vagy vannak-e tapasztalataik a mobilitásról, tapasztalataikban hogyan jelennek meg a mobilitással kapcsolatos sikerek és kudarcok, milyen tapasztalataik vannak a tapasztalatokról, szeretne-e illetve mer-e az adott személy elmozdulni szülőfalujából, jelenlegi otthonából.

Az esettanulmány e dimenziókat követi, az egyes fejezetek azonban reflektálnak az esettanulmány eredményeire is. Fontos az élettörténetekben megjelenő mobilitás, ami egyrészt a fiatalok tanulmányaihoz, munkavállalásához kapcsolódik, másrészt a családi történetekben, a helyi és családi tudásban jelennek meg. De legalább ennyire fontos látnunk, hogy az apróbb mozgások (ügyintézés, bevásárlás, kirándulás), valamint a problémák esetén felmerülő mobilitás hogyan jelenik meg a fiatalok és szüleik interjújában, vannak-e generációs vagy intergenerációs azonosságok. A bátorságot, a félelmet, az egyedüllét vállalását is vizsgálhattuk, ahogy a személyes tapasztalatokban és mások tapasztalataiból leszűrt sikereket és kudarcokat is. 


\section{TEMATIKUS TANULMÁNYOK - Községekben élő immobil fiatalok}

\section{Elméleti körüljárása a maradásnak és a kudarcos mobilitásnak}

Amikor mobilitásról beszélünk, látjuk magunk előtt a fiatal, vállalkozó kedvű, lendületes, reményteljes, bizakodó vagy épp menekülő, elvándorló egyént és csoportot, mégis, legalább ennyire fontos látnunk azokat, akik, noha volt esélyük, lehetőségük kipróbálni magukat máshol, mégis visszatértek, vagy el sem indultak, el sem indulhattak. Ezen egyének csoportjait a mobilitásvizsgálatok peremterületén találhatjuk meg: ők az ellenpélda, de nem az ellenpont. Ők lesznek azok, akik nem mentek el, s ha mégis, visszatértek, s útjukat a félelem, a kudarc, a kötődések mentén rajzolják fel. De nem feledkezünk meg arról sem, hogy a közösség, az előző generációk támogatják-e a mobilitási elképzeléseket, a szaktudás és a tőke segíti-e azokat, akik távozni szeretnének. Éppen emiatt a kiegészítő jelleg miatt nagyon fontos, hogy megismerjük azoknak a mobilitástörténetét, tapasztalatát, a migrációhoz való viszonyulását, akik maradtak - leültek (Jónsson 2011), nemet mondtak a távozásra, vagy egyszerüen nem is volt más lehetőségük. Sokféle oka lehet a maradásnak, s ezek egy része felismert, megfogalmazott ok (a kockázatkerülés, a szegénység), mások azonban elfedve befolyásolják a döntést, ilyen például a fejlődési képesség hiánya (iskolázatlanság például), a tőke hiánya, a helyi kötések (és források) elvesztésének lehetősége. Ezen okok mellett említi Carling (2002) azokat az okokat is - melyek számunkra itt kevésbé relevánsak -, mint a belföldi migráció elégséges volta, vagy a kivándorlást gátló tényezők. A migráció kutatói valóban az elvándorlás változatait, okait, hatásait veszik szemügyre (ld. Schewel 2019), e tanulmány mégis annak szenteli a figyelmet, hogy mi történik akkor, amikor a szülők vagy az egyén generációjában megtalálható a migráció, a területi elmozdulás, azonban az nem a migrációt, hanem a maradást erősíti meg.

\section{Egyedül elindulni, elköltözni, lenni}

A mobilitások elsősorban a tanulmányokhoz, a környező településeken történő munkavégzésekhez és az apróbb ügyintézésekhez, bevásárlásokhoz kapcsolódnak. A nagyobb távolságra való költözés kapcsán az interjúalanyok - a fiatalok generációjából - a kihívásokat, a nehézségeket, az idegen környezetet, az otthon hiányát említik. Többen nem is kívántak belevágni, mások nem látták kivitelezhetőnek, hogy ott, messze megteremtsék a minimális egzisztenciát, legyen hol lakniuk, fizetni tudjanak mindent és megmaradjon élőnek a kapcsolatuk az otthonnal. Mások belevágtak és visszafordultak, ahogy egyik interjúalanyunk fogalmazta meg a feltételezéseit, hogy 


\section{TEMATIKUS TANULMÁNYOK - Községekben élő immobil fiatalok}

„Szerintem azért is, mert ő is rájött arra, hogy máshol sem jobb élni.” (Az interjú alanya fiatal, egyedülálló hölgy, aki maga rendelkezik mobilitási tapasztalattal, de nem kívánná elhagyni a falut).

Látjuk azonban, hogy majdnem minden interjúalany tud olyan személyt a környezetéből, a családjából, aki sikerrel ment el és telepedett le másik településen.

A szülői interjúk némelyikében merül fel, hogy a munka, a szórakozás megkívánja, hogy a fiatalok elmozduljanak, de mégsem mennek el.

„Szerintem félnek megmozdulni a fiatalok, el vannak itt kényelmesedve. Anyu meg apu eltart mindenkit." (Az interjú alanya középkorú közfoglalkoztatott nő, aki támogatja a mobilitást)

A félelem mellett felmerül a kilátástalanság, reménytelenség mint visszatartó erő, de az idősek, annak ellenére, hogy látják a helyhez kötöttséget, akárcsak a saját életükben is, többségében szeretnék, ha a gyermekeik elmennének a lehetőségeik irányába.

Sok interjúból úgy tűnik, hogy az emberek maradnak a falujukban, másokból úgy tűnik, hogy az ingázás belefér az életükbe, még inkább más interjúkból azt is látjuk, hogy vannak minden generációban, családon belül és kívül olyanok, akik a következő falu vagy város határán is túl mentek. Mégis, vannak, akik meg tudják fogalmazni, hogy az elköltözés ellenében hat a család, a kötöttségek, a tulajdon, a ház, amelyet magukénak mondhatnak.

Ezt és az elmozdulás képtelenségét írja le az interjúban az egyik felsőfokú tanulmányokat folytató interjúalanyunk is:

„[H]a tehetnénk se tudnánk költözni, mert ugye ott van házunk, ott élünk. És anyagilag nem tehetnénk meg, hogy egy lakást vagy akár vásároljunk, vagy akár csak albérletbe menjünk bárhova is. És én sosem voltam albérletben..." (Az interjú alanya érettségizett fiatal nő, nem mobil családból, kisebb mobilitási tapasztalatokkal és lehetőséggel arra, hogy maradjon a falujában.)

Izgalmasnak tűnik, hogy az igazán immobilnak nevezhető interjúalanyaink menynyire korlátozottan érdeklődnek a mobilitás iránt, sem elvándorlásról, sem azt követő visszaköltözésről nem vagy nagyon kevéssé tudnak, az olyan lehetőségeket pedig, amelyek azzal járnának, hogy őt magát is mobilizálják, mintegy észre se veszik.

A kudarccal végződött távoli munkavállalások igen sokszínűek, s több helyen ezen esettanulmányban visszatérünk rá, hogy milyen okokat tételeztek interjúalanyaink, miért végződött hazatéréssel a munkavállalás (említeni kell a távolságot a családtól, a megszokottól, a nyüzsgést, zajt, az új helyen hiányzó komfortot, ott- 


\section{TEMATIKUS TANULMÁNYOK - Községekben élő immobil fiatalok}

honosságot, a nagyvárosi élet sajátságait, a barátságosság hiányait stb.). Emellett a kezdeti nehézségekkel való megküzdés is problematikus lehet, a türelmetlenség is a feladáshoz vezethet:

„Csak a stabilitás hiányzott. Tehát gondolkozni kellett a dolgokon. Ezt is be kell szerezni, el kell intézni, meg kell csinálni. Otthon meg csak le kéne feküdni és hagyni mindent, ahogy van. Itt pedig szenvedni kell." (Interjú egy nem mobil családból származó, kényszerből maradó érettségizett fiatal férfival)

Csak néhány esetben merül fel a honvágy mint visszahúzó erő, amely rövidebb-hosszabb eltávozáskor is megjelenik (egyik interjúalanyunk azt mondta, hogy a honvágy nem, hanem a megszokás az, ami visszahúzza). A honvágy mellett az otthonosság, amely az elköltözés ellenében szól: a helyiek, a helyek ismerete, a kapcsolatok mellett olyan fontos apróságok is megjelennek, mint a „házikoszt”, az interjúalany édesanyjának fóztje vagy épp a háziállatok, házikedvencek.

Jellemző még, hogy az interjúalanyok valamilyen módon megfogalmazzák a kötelmek mellett a lehetőségek hiányát is, amely visszatartja az embereket a költözéstől:

„Muszájság, munkahely, ez van, ezt kell szeretni, a gyermekeinek nem ezt gondolja az ember., ók csak menjek, arra, amerre tudnak. Ne maradjanak itt." (Interjú egy általános iskolai végzettséggel bíró középkorú nővel, aki ugyan mobil családból származik, de azt kívánja, hogy a fiatalok maradjanak.

Kuriózumként említhetjük egyik interjúalanyunkat, aki teljes mértékben ideiglenesnek tekinti azt az állapotot, hogy nem költözik el, nem szeretne helyben maradni, hetelős képzési, illetve ingázásra vonatkozó tapasztalatokkal rendelkezik, de az életszínvonal, a szolgáltatások elérhetősége az, ami elsősorban távozásra késztetné.

\section{Mobilitás az élettörténetben}

\section{EGYÉNI MOBILITÁS ÉS TANULMÁNYOK}

Néhány interjúalanyunk arról számolt be, hogy az elvégzett általános iskolai tanulmányai a saját településen belül kerültek befejezésre, néhányan közülük nem is folytatott középfokú tanulmányokat, mások elkezdték, de nem fejezték azt be.

Az élettörténeten belül a mobilitás mintázatai a felső tagozat, illetve középfokú tanulmányok végzése kapcsán jelennek meg, ezek jellemzően a szomszédos településeket vagy a vonzáskörzet súlypontját jelentő településekhez való kapcsolódást 


\section{TEMATIKUS TANULMÁNYOK - Községekben élő immobil fiatalok}

jelentik, de ez még nem oka közvetlenül a tartósabb elvándorlásnak. Sokan ekkor is, ha tehetik, otthonról járnak be, ún. bejárósként végzik az iskolát. Az iskolaválasztásnál fontos szempont a távolság és az, hogy a fiatal szeretne-e a családi fészektől távol élni vagy bejárósként tanulni. Vissza-visszatérünk az interjúkban arra, hogy a magasabb iskolai osztályok elvégzése is egy szúk 5-30, maximum 60 km-es körzetben történik.

A felsőfokú tanulmányok már inkább kimozdítják a fiatalokat, ha van lehetőségük, hogy az utazást, kollégiumot fizetni tudják, ha van motivációjuk, de több egyetemi hallgató interjúalanyunk megerősíti, hogy a település visszavárja, diplomás munkahelyet biztosít számára a végzés után.

A kistelepüléstől való távolmaradás fontos lépcsője tehát a távoli tanulmányok idejére bevállalt ottlakás, a kollégiumi vagy albérletbeli szállás igénybevétele. Több fiatal interjújában is megjelenik, hogy a középiskolai tanulmányok idejére vagy annál rövidebb időre vállalták a távolmaradás ezen formáját. Igaz, az is előfordul, hogy a kollégiumi élet nem volt a kedvükre való, nem bírták és így egy idő múlva a bejárós módszert választották, azaz inkább keltek korán és ingáztak a középiskolai tanulmányok során, mintsem hogy az otthoni kényelemről lemondjanak. Egyes fiatal interjúalanyaink beszámolnak arról, hogy eleve nem kívántak kollégiumban vagy albérletben lakni, inkább választották azt, hogy minden nap hazajönnek a településükre.

Az Arany János Tehetséggondozó Program szerepe is megjelenik az egyéni élettörténetek körében: néhányan részesei voltak a programnak, s középiskolai tanulmányaikat az AJTP támogatásával folytatták, ennek keretében vettek részt a falujuktól távoli oktatásban, tehetséggondozáson és kollégiumi programokon.

\section{Egyéni mobilitás és munkavállalás}

Miközben a legtöbb interjúban a megkérdezett fiatalok a falubeli munkáról, a falu „vonzáskörzetében” lévő munkahelyről vagy a közeli nagyvárosban eltöltött munkáról és gyakorlatról beszélnek, alkalmanként megjelenik valamely távolabbi földrajzi ponthoz kapcsolódó munkatapasztalat is. Egyik interjúalanyunk például fél évet töltött a társával Londonban, s még ha számos szempontból vonzónak is találta (minden szolgáltatás elérhető, kedvesek az emberek, kedvesebbek, mint a magyarok, meg volt elégedve a jövedelmével, a helyi közlekedéssel), mégis megviselte a kint töltött idő, a nagyvárosi nyüzsgés.

Több fiatal interjújában szembetűnő és bevallott, hogy nem is merült fel, hogy a falutól távol vállaljon munkát, hogy a munkavállalás miatt elköltözzön.

„[D]e én ilyen földhözragadt vagyok és sehová nem megyek. Kellene egyébként, hogy az ember lásson más dolgokat is vagy hogy kimozduljon, pihenjen. 


\section{TEMATIKUS TANULMÁNYOK - KöZségekben élő immobil fiatalok}

Szerintem kellene, de... na." (Érettségizett fiatal nő, aki lehetőséget talált a faluban)

A fiatalok is megállapítják, hogy a karrierhez az elmozdulás, a mobilitás szükséges, egy tanfolyam, képzés, amelyet más településen tartanak, hozzájárulna az előremozdulásukhoz, azonban nem mindenki akar vagy képes ilyen áldozatot hozni, az adott státuszuk megőrzése és a mindennapi életük fenntartása ezt nem követeli meg, „csak” a fejlődés.

Egyes interjúalanyok a településüktől távolabbra is eljárnak dolgozni, de onnan napi szinten is hazajárnak, akár 30 km-ről is, ilyenről számol be a nagy mobilitást igénylő, útépítésen édesapjával dolgozó interjúalanyunk is, mégis, amikor arra kérdeztünk rá, hogy vállalna-e távolabbi munkát, gondolt-e ilyesmire, nemlegesen válaszolt.

A falutól való távolság, a hazajárás lehetősége, a hazajárás gyakoriságának lehetősége meghatározza, hogy milyen messze vállalnak munkát, így egy hetes távollétet vállalhatónak találnak, miközben ennél hosszabb ideig, hónapra vagy hónapokra való távolmaradást már nem vállalnának.

Ritkán merül fel az interjúalanyok körében, hogy egy már elszenvedett kudarc után újrapróbálkoznának egy mobilitással, akár külföldi úttal, de ilyen is előfordul, igaz, az elbeszélés alapján nem lenne ez sem tartós, sem ami az elbeszélt múltat, sem, ami a terveket illeti: egy pár év múlva visszatérne és a kint megtakarított pénzével letelepedne.

\section{Mobilitás gondolata, ha jönnek a gondok}

A munkahelyen előforduló nehézségek, személyes sérelmek kapcsán olykor felmerül a gondolat, hogy az interjúalanyok elvándorolnának, de az ehhez vezető cselekvésig már nem jutnak el, többségében a döntésig sem.

Az élettörténetekben megjelennek törések: terhesség miatt félbeszakadt középiskolai tanulmányok, otthagyott iskolai tanulmányok stb., s ezek mind a faluba való visszahúzódást erősítették meg. A törések nem feltétlenül értékelődnek kudarcként, inkább csak egy olyan változásként, ami miatt akár a mobilitás, akár a tanulmányok, munkavállalói tevékenység megszakad.

\section{Apróbb távozások: ügyintézéstől a nyaralásig}

A fiatalok interjújában fel-feltűnnek hosszabb-rövidebb utazások, 1-2 napos budapesti tartózkodás, Tisza-parti nyaralás, Balatoni napok, jellemzően azonban a régión belülre mutató utazások ezek. Ahogy a bevásárláshoz, ügyintézéshez kapcsolódó 


\section{TEMATIKUS TANULMÁNYOK - Községekben élő immobil fiatalok}

utazások is: a legtermészetesebb, hogy a kistelepüléseken a nagyobb bevásárlásokat nem lehet vagy nem érdemes intézni, az ügyintézés is a közigazgatási központokban valósul meg, így ezen tevékenységek bizonyos gyakorisággal megjelennek az interjúalanyok életében.

Azonban ezen apró távozásoknak is lehet, hogy van akadálya, a tömegközlekedés elégtelen volta, az átszállás megnehezíti a tervezhetőséget, az időtakarékosság is fontos, s így együttesen nehézségként merül fel:

„Mondjuk nekünk innen elég nehéz bármilyen utat is összehozni, mivel [interjúalanyunk településéröl] közvetlenül nem sok nagyobb városba lehet eljutni, tehát mindenképpen, ha busszal megyünk is át kell szállni, ha autóval megyünk is nagy a távolság [...] Ha esetleg vonattal megyünk valahova, akkor [említ két települést] be kell jutnunk, mivel itt nincs vasútállomás, úgyhogy mi ha bárhova utazunk, azért eléggé meg kell szervezni, hogy hogy legyen az odaút, a visszaút, hogy hogy a legegyszerübb, hogy időben hogy tudunk a legtöbbet megspórolni." (Mérlegképes könyvelő fiatal nő, aki szereti a faluját)

A diákmunka, nyári munka tapasztalatai a fiatalokat részben helyhez kötik, kis részük azonban a településen kívül is vállal munkát, ez azonban nem olyan meghatározó élmény, mint a nagyobb volumenű, tartósabbnak tervezett távozások, költözések, úgy tűnik, nem hatnak nagy mértékben a mobilitásra.

\section{Mobilitás a családtörténetben}

A mobilitás tekintetében nagyon fontos, hogy milyen mintát lát a család és a fiatal, vannak-e példák előttük. Számos esetben kisebb-nagyobb mobilitásról beszámolnak az interjúalanyok, ahogy rokonok, családtagok, falubeliek 50-70 km-re ingáznak, a környező településekre átjártak dolgozni - elsősorban az iparban, feldolgozóiparban, építőiparban találva maguknak állást. Megjelennek a napszámos munkák is, s a jelenhez kapcsolódóan a külföldi gondozói állások is.

Történeteik azonban arra is alkalmasak, hogy lássuk, a minta, a mobilitás mintája jelen van, mégsem jelent a fiatalok számára követendő példát, érintőlegesen ismerik a mintákat, mégha beszélnek is ezekről a dolgokról a családtagokkal, bizonytalan a tudásuk.

Ahogy az egyéni interjúk során az élettörténetben, úgy a családi mobilitástörténetben is megjelenik az, hogy a szülők, nagyszülők az iskolai tanulmányok miatt - felső tagozatos általános iskolai, középfokú tanulmányok - más településre kellett, hogy átjárjanak.

A falubeli rokonok hasonlóan végzik tanulmányaikat: amennyiben az adott település nem teszi lehetővé, az egyénhez hasonlóan ingázva végzi tanulmányait. Úgy 


\section{TEMATIKUS TANULMÁNYOK - Községekben élő immobil fiatalok}

tűnik azonban, hogy amennyiben a felsőfokú tanulmányokra is sor kerül, akkor a falutól való távolmaradás tartóssá válhat, máshol telepedhetnek le.

Egyik fiatal beszámol arról, hogy édesapjával együtt jár dolgozni, ahogy fogalmaz, ők „Magyarország egész területén” dolgoznak, útépítéssel foglalkoznak. (Az interjú alanya alacsony iskolai végzettségú fiatal férfi, aki úgy érzi, hogy kényszerhelyzetben volt.) Ez azonban ritka, mind a mobilitás, mozgékonyság kiterjedtsége tekintetében, mind pedig az intergenerációs együttmúködés tekintetében.

Ha a családtagokkal készült interjúkat tekintjük, látjuk, hogy régebben nagyobb területen belül és változatosabban ingáztak a falubeli családtagok: a rendszerváltás előtt többen vállaltak munkát, a munkavállalók egy része pedig a falutól távol helyezkedett el, oda napi vagy heti rendszerességgel ingázott, nagyobb távolságra (pl. Dunántúl) is elindultak dolgozni, de a közeli települések tekintetében is számosabb helységnév merül fel, mint a fiatalokkal készült interjúkban.

Miközben a legtöbb interjúban a mobilitás uralkodik, egyik interjúalanyunk megállapítja, hogy a régi termelőszövetkezeteknek nagy volt a megtartó ereje, ezért akkor kevesebbek számára merült fel az elvándorlás is, hiszen volt biztos munkahelye, munkája az embereknek.

Egyik interjúalanyunk nevén említi a fekete vonatot, amellyel a környékbeliek Budapestre ingáztak a rendszerváltás előtt, hetelős munkára.

A családtörténetben megjelenő nagyobb mobilitás oka a távolabbi munkalehetőség és a jobb anyagi lehetőségek, amely a jelenlegi mobilitásnál is okként feltételeződik, mégis érzékelnek különbséget. Az interjúalanyok arról számolnak be, hogy

- a rendszerváltás előtt többen dolgoztak,

- a fiatalok kevésbé motiváltak a munkavállalásra,

- a rendszerváltás előtt helyben is lehetett találni (és többféle) munkáltatót,

- jelenleg a közeli centrum jelenti a munkalehetőséget vagy még távolabb, helyben kevés munkalehetőség és közmunka maradt,

- a mobilitás régen kifizetődőbb volt, támogatott volt,

- a jelenlegi utazási költség és/vagy albérlet árak mellett nem lehet ingázni,

- az otthonteremtés könnyebb volt,

- sok fiatal (több interjúalanyunk is) a szüleivel él.

Az otthonteremtés vonatkozásában fontos megállapítást tett az egyik interjúalanyunk a szülők generációjából, és gyermeke is, arra utalva, hogy a mobilitásnak gátja az is, hogy a falusi házak eladásából nem lehet városba költözni, pláne nem kertes házba.

„A lakást nem tudjuk eladni, mert az ára nagyon olcsó. Nagyon alatta vannak a lakás árak, az ingatlan árak." Interjú egy alacsony iskolai végzettségú középkorú nővel, aki a mobilitás ellen van, igaz, maga is kényszerből maradt.) 


\section{TEMATIKUS TANULMÁNYOK - KöZségekben élő immobil fiatalok}

A kertes ház megléte azért is merül fel e családon belül (ld. Kertész végzettségű fiatal nő, aki kényszerből maradt a településen - interjú), mert a veteményesben megtermelt javak és az állattartás összességében kiegészítik a család jövedelmét, s amennyiben ez egy erős szempont, a mobilitás ellenében hat.

Az idősebb interjúalanyok (a szülők generációjából valók) körülírják, megfogalmazzák a megszokást: ide születtek, itt voltak gyerekek, jártak iskolába, megszokták, hogy ügyes-bajos dolgaikat elintézni nagyrészt egy közeli másik településen tudják, de említik, hogy itt történtek velük a legfontosabb dolgok is: a szerelmek, a barátságok, a gyermekek születése. A megszokás mellett a gyökerek és a tulajdonok is nagy szerepet kapnak a mobilitás hiányában.

„[M]ivel anyáék is itt laktak. Ide építkeztek. Tehát itt nőttem fel. Sohasem került szóba az, hogy fogalmam sincs, hogy ook is miért nem gondolták azt, hogy költöztek ők is városba. Miért volt ez az ötlet, hogy építkezzenek. Tehát sosem merült fel gyerekkoromban sem, hogy mi beköltözzünk Barcikára [...] mivel én így nöttem fel, így soha nem vágytam el, nem volt az, hogy mi elmenjünk innen. Meg volt itt nekünk minden. Jól éreztük magunkat." (Interjú érettségizett fiatal nővel, akinek a családja is mobil, de megtalálta a számítását a faluban)

„Voltak terveim, hogy megyek máshová, de viszont azt is figyelembe vettem, hogy itt van mindenünk felépítve, hogy egzisztencia, ilyesmi. Ha összepakolsz mindent, akkor nekem ez így nehézkes, mert csak hajtanom kell, de jó itt lenni..." (Interjú középkorú hentes férfival, aki megtalálta a lehetőségeit a faluban)

„Ide köt minket minden, a családot. Amit édesapám itt felépített dolgokat. Tényleg teljesen mindent, egzisztenciát, kapcsolati tőkét, ilyesmit. És most hogyha ezt felrúgja az ember, akkor utána máshol majd építsen ki megint egyet? Ez így a legegyszerübb megoldás szerintem." (Interjú középkorú hentes férfival, aki megtalálta a lehetöségeit a faluban)

„Itt van mindenünk kész. Én már nekem az az idő, ami hátravan, nem tudom, kinek mennyit szabnak, én nekem az már... én már nem akarok belefogni másba. Ez már megvan, ezt kell megőrizni. Nem. Igazából nem tervezem, hogy még az utolsó 20, vagy 40, vagy 30 évet még azzal foglalkozzak, hogy még építsem magamnak, meg... nem. Ez már megvan, ezt kell megörizni. Ezt kell használni, kész." (Interjú szakmunkás férfival, aki a falusi életmód miatt maradt.)

Egyik interjúalanyunk osztotta meg azon gondolatát, hogy ő - az idősebb generációból - már nem kezdene bele az elvándorlásba, messze munkalehetőséget keresve, elmozdítva a családot, s még ha a gyermekei már felnőttek is, együtt mozdulnának. 


\section{TEMATIKUS TANULMÁNYOK - Községekben élő immobil fiatalok}

„[A]nnyira együtt vagyunk már, hogy valahogy-valahogy muszáj kibírni ebből a kis munkabérből, ebből a kis közmunka bérből, sajnos. Hát valahogy beosztjuk." (Interjú egy mobil családból származó férfi közmunkással, aki kényszerböl maradt.)

A családtörténetekből kirajzolódni látszik az, hogy az idősebb generációk alacsonyabb iskolai végzettséggel (6 osztály, 8 osztály, szakvégzettség) rendelkeznek, a gyermekeik esetében már gond ot fordítottak arra, hogy a helyben elérhető képzés mellett más, távolabbi képzésbe is bekapcsolódjanak és ez a generációk előrehaladásával egyre kiterjedtebb. Az idősebb generáció nőtagjai sokszor háztartásbeliként a gyermekneveléssel, háztartással, konyhakerttel és erőforrásaik, lehetőségeik megléte esetén napszámmal voltak elfoglalva, a későbbi generációk esetében ez utóbbi helyére lépett be a munkahely, a konyhakert, és háztáji lassan háttérbe szorult. A középgeneráció (azaz az interjúk tekintetében a szülők generációja) látja, érzékeli a változásokat, érzékeli, hogy a korábbi időszakokban más volt a mobilitás, de mégse szívesen enged az újabb mintának, amely esetében a fiatalok nagyobb távolságra, messzebb kerülnek a családtól. A fiatalok számára az, hogy az iskolai tanulmányok befejezése, illetve hogy az egyes ügyintézés, valamint a nagyobb bevásárlás egy másik településen történik, természetes. Az idősebbek esetében nem egyértelmüen folytatódott egy másik településen a tanulás, az ügyintézés nagyrészt a település-központban megoldható volt, a háztáji pedig részben fedezte szükségleteiket, bevásárlást is helyben eszközöltek.

Fontos, hogy az interjúkból kitűnik, az idősebb generáció háttérbe húzódik, ha a mobilitás döntéséről van szó, azaz amikor a fiatalnak el kellett döntenie, hogy marad vagy megy tovább, hogy bejárós vagy kollégista lesz, a szülők meghagyják a döntés jogát, a fiatalok pedig döntenek - és olykor csalódtak, változtattak. Szépen összefoglalja ezt egy interjúalanyunk a szülők generációjából:

„Nekem az volt az elképzelésem, hogy ö döntse el, hogy mit szeretne, mert ugye egy tizennyolc éves gyereknek már el kell tudni dönteni, hogy mit szeretne. Döntse el, hogy mit szeretne. Ö eldönti, hogy ezt szeretné, innentöl kezdve, amit tudok rajta támogatni, azt megadom neki. És haladjon." (Interjú a középkorú hentes férfival, aki megtalálta a lehetöségeit a faluban.)

A mobilitást gátló tényezőkként merülnek fel azok a családtagok, akik számítanak a segítségre, de bizonytalan, kiszámíthatatlan helyzetbe nem mozgathatók (kisgyermek) vagy megszokták a településen, onnan el se mozdulnának (nagyszülők generációja). Ezen elbeszélések nem burkolóznak be a csalódottságba, egyszerű közlésként jelennek meg, magyarázatként arra, hogy miért is nem menne el a család, a fiatal adott településről. 


\title{
TEMATIKUS TANULMÁNYOK - Községekben élő immobil fiatalok
}

\section{Siker, kudarc, félelem}

Az interjúkból a mobilitással kapcsolatos félelmek személyesek, illetve a családot érintik, míg az igazi siker- és kudarctörténetek jellemzően falubeliekkel, távolabbi rokonokkal esnek meg, mégis vannak személyesebb esetek, ezekben gyakori a kudarc visszatérő képe, de az is, hogy sikerülhet - neki vagy másnak, de sikerülhet.

\begin{abstract}
„Én elmentem, de vissza kellett jönnöm, mert rossz volt a munka. De hát mást nem tudok, aki visszakényszerült volna G-ra. Csak olyanról tudok, aki elkényszerült innen. Tehát már nem tudott itt maradni egyszerüen. Nem volt az a lehetőség, hogy mindentől ennyire messze legyen. Ez már luxus, ha az emberek itt élnek." (Interjú egy nem mobil családból származó, kényszerből maradó érettségizett fiatal férfival)
\end{abstract}

\section{Sikerek a mobilitás során és okán}

Interjúalanyaink többsége nem számol be személyes sikerekről a mobilitásához kapcsolódóan, elsősorban azért, mert ha távozott is egy másik településre, az ország másik részébe, vagy másik országba, onnan hazatért. Ennek ellenére látják, hogy vannak a saját generációikban és más generációkban is olyanok, akik sikerrel jártak, évek óta élnek választott helyükön, megélnek, családot alapítottak, alkalmanként járnak csak haza és az interjúalanyok tudomása szerint jól érzik magukat. Annak kapcsán, hogy interjúkészítőnk kérdezte, interjúalanya ismer-e olyan pozitív történetet, melyben valaki elment, és elhelyezkedett sikeresen, interjúalanyunk így fogalmazott:

„Szerintem annak, aki elment és nem jött vissza annak javarészt.” (Érettségizett fiatal nő, akinek a családja is mobil, de megtalálta a számítását a faluban)

A távolabbi családban megjelenő sikeres mobilitás kapcsán jegyzi meg egyik fiatal interjúalanyunk:

„Ők így innen kiszabadultak, hál' Istennek, nekik bejött az élet.” (Interjú egy fiatal, 8 osztályt végzett, mobilitását vesztett fiatal nővel)

\section{Kudarcok a mobilitás során és okán}

Fentebb már megjelenítésre került, hogy volt, aki külföldi munkavállalással próbálkozott és személyes kudarcként élte meg, hogy miközben megfelelő életszínvonalat sikerült kialakítaniuk, elérniük, talán lehetőségük is lett volna fejlődni, személy sze- 


\title{
TEMATIKUS TANULMÁNYOK - Községekben élő immobil fiatalok
}

rint nem bírta a változásokat, a nagyvárosi életet, így haza kellett jönniük egy félév után. Ugyanő említi azt is, hogy egy hasonló helyzetben valószínűleg hasonlóan kudarcot vallana ismét. Az édesanyja ugyanakkor nem érzékeli vagy nem érzékelteti kudarcként:
„Minden kezdet nehéz máshol. Hát meg próbáltam én is elmenni, visszajöttem, meg volt amikor a lányom is elment, de ők is visszajöttek. Végül mindenki visz- szatért szinte." (Interjú egy idősebb hölggyel, aki kényszerből maradt a falu- ban)

A kudarcért nem kell külföldre menni, egyik édesapa budapesti munkájára emlékezve mesélte, hogy alig várta, hogy hazamehessen, nem bírta az ottlétet és a családtól való távolságot sem. Főiskolai hallgató interjúalanyunk és mások is beszámolnak arról, hogy az általuk meglátogatott nagyváros, főváros zajos, zsúfolt, az emberek rohannak és ingerültek, bunkók, így nem érezték jól magukat, várták, hogy hazamehessenek, belátva azt, hogy ez csak az ő személyes elkötelezettségük, hiszen vannak akár közeli hozzátartozóik, akik boldogulnak, elégedettek a városban. A különbségtevések azonban mégis legitimálják az interjúalanyok egyedi döntéseit: a városiak másként gondolkodnak, másképp látják a dolgokat, más zavarja őket, más dolgok a fontosak, ezekkel szemben fogalmazzák meg a falusi létet és mindazt, amit ők fontosnak tartanak (nyugalom, barátság, családi kapcsolatok, település iránti elkötelezettség, kiszámíthatóság). De kirajzolódik az adaptálódás hiánya is, amelyet egyik interjúalanyunk úgy fogalmazott meg, hogy ő nehezen alkalmazkodik, ez vezetett kudarchoz.

Kudarcként nevezi meg interjúalanyunk, ugyanakkor mintha gazdaságossági megfontolás lenne azok mögött a meg nem nevezett történetek mögött, amelyikben a visszaköltözés azért történt meg, mert többet tudtak a fiatalok megtakarítani, ha otthon maradnak:

\begin{abstract}
„Voltak olyanok, hogy elmentek, mert úgy gondolták, hogy városon másabb az élet, jobb lesz, munkahely meg minden, de utána mégis rájöttek, hogy csak visszajönnek, mert, amit ott keresnek az elmegy, akkor az albérletre, meg a rezsire. Itthon meg ugye itthon vannak a szülók és, akkor inkább elment ide dolgozni és akkor több pénze maradt meg, jobban tudott spórolni, meg tudott a szülőknek segíteni." (Interjú egy érettségizett középkorú hölggyel, aki maga ugyan kényszerúségből maradt, de a fiatalok számára a mobilitást ajánlaná.)
\end{abstract}




\section{TEMATIKUS TANULMÁNYOK - Községekben élő immobil fiatalok}

\section{Félelmek a mobilitással kapcsolatban}

Amint a gyermekek elmozdulnak, elmozdulnának a faluból és máshol folytatnák a tanulmányaikat, a szülők visszaemlékezéseiben megjelenik az utazás nehézsége, az akadályok leküzdésének kérdése, hogy tudnak-e a távolból megfelelő segítséget nyújtani, ha az szükséges. A távolság kapcsán a tömegközlekedés ritkasága, nehézségei jelennek meg, ezt csak az autóval való rendelkezés enyhíti:

„[N]agyon nehéz ez itt a mi községünkbe ez az elmenetel, hazajövetel. De már most hála Istennek már most nem, most segítség annyi van, hogy autóval tudok járni és tudom óket vinni, hozni. De régebben nehéz volt, mert akkor nem volt autó és busz meg vonat volt." (Interjú egy középkorú közfoglalkoztatottal, aki a fiatalok mobilitását megérti.)

A szülői interjúkból kitűnik az aggodalom más vonatkozása, vajon mit csinál a fiatal, amikor egy másik településen él a tanulmányai miatt, ha fiúgyermek, akkor vajon rendben jár-e iskolába, ha leánygyermek, akkor nem esik-e bántódása. Ezek az aggodalmak kirajzolódnak az olyan családokban is, ahol van mobilitási minta, de ott is, ahol nincs ilyen minta.

Ellenkező irányú félelmet is azonosíthatunk: több szülő jelzi, hogy nem szeretné, ha a fiatal, a gyermeke, gyermekei a faluban telepednének le, számukra - úgy érzik - még nyitva egy gyümölcsözőbb jövő. De nagyon szépen fogalmazza meg a jövő generációjával kapcsolatos elképzeléseit egyik szülő interjúalanyunk:

„[É]n szeretném, hogy vidéken éljenek. Ha nem is vidéken, akkor családi házba. Aztán az ország határain belül, ne külföldön." (Interjú egy szakmunkás középkorú férfival, aki szereti a faluját és ezért nem menne el.)

\section{Összegzés}

A megismert interjúkban vissza-visszatérnek a mobilitás elemei: falubeliek, rokonok, családtagok, maguk az interjúalanyok másik településen hosszabb-rövidebb időre megfordulnak, látnak sikereket, kudarcokat mások és saját történeteikben, látják a helyhez kötöttség vonatkozásait, a költözés előnyeit és még inkább a hátrányait.

Az interjúk olvasása során azon gondolkodtam, hogy miért nem látszik, miért nem nyilvánvaló az az összefüggés, hogy az idősebb generáció mintái, mobilitása, mozgékonysága - ha volt ilyen -, hatna a fiatalra vagy épp a mobilitásba vetett bizalma visszatükröződne a gyermeke interjújában. Az idősebb interjúalanyoktól választ is kapunk: a változó feltételekben látják a különbséget, az eltérő habitusban, 


\section{TEMATIKUS TANULMÁNYOK - Községekben élő immobil fiatalok}

a generációk közötti különbségekben, de összességében olvasóként, értelmezőként nem egyértelmű, hogy az idősebbek mobilitási tapasztalatai vagy elképzelései a fiatalokban visszaköszönne, más értékeket, félelmeket, tapasztalatokat, kötődéseket helyeznek előtérbe.

Az esettanulmány rávilágít arra, hogy a kistelepülésen élő fiatalok immobilitását nagyon sok tényező együttesen okozza, amely az anyagi megfontolások és a szubjektív kötődések és félelmek dimenzióiban ábrázolhatók. Az anyagi megfontolások magukba foglalják az albérlet drágaságát, a falusi otthon eladásából nem származik annyi pénz, amely egy lakás vagy még inkább kertes ház vásárlására elegendő lenne, a lakhatás és közlekedés együttesen drága, a veteményesből, háztájiból vagy napszámból bejövő bevételek kiesnének stb. A szubjektív kötődések az otthonhoz, a családhoz, a hely ismeretéhez, a békés, nyugodt élethez vagy épp a házikoszthoz kötődnek, ezeket egészítik ki a félelmek, amelyek az egyedüllétből, az egyedül vállalt döntésekből és megoldásokból adódnak, a bizonytalanságból, az újrakezdés nehézségeiből, a támogató háttér hiányából (vagy pontosabban annak távollétéből) eredeztethető.

\section{Irodalom}

Carling, J. (2002): Migration in the age of involuntary immobility: Theoretical reflections and Cape Verdean experiences. Journal of Ethnic and Migration Studies 28(1). 5-42. https://doi.org/10.1080/136918301201039124

Jónsson, G. (2011): Non-migrant, sedentary, immobile, or 'left behind'? Reflections ont he absence of migration. IMI Working Paper Series, 39. https://www.oxfordmartin.ox.ac.uk/downloads/academic/wp-11-39-non-migrant-sedentary-immobile-or-left-behind.pdf (Utolsó letöltés: 2019. augusztus 2.)

Shewel, K. (2019) Understanding Immobility: Moving Beyond the Mobility Bias in Migration Studies. International migration Review. https://doi.org/ 10.1177/0197918319831952 